\title{
Charles D. Sabatos, Frontier Orientalism and the Turkish Image in Central European Literature, Lanham, MD: Lexington Books, 2020. pp. xx+184. ISBN 978-1793614872
}

\author{
C. Ceyhun Arslan* (i)
}

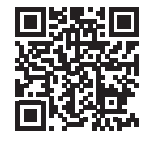

"Asst. Prof., Koç University, College of Social Sciences And Humanities, Comparative Literature, Istanbul, Turkey

ORCID: C.C.A. 0000-0001-8048-3775

Corresponding author/Sorumlu yazar: C. Ceyhun Arslan,

Koç University, College of Social Sciences And Humanities, Comparative Literature, Istanbul, Turkey

E-mail/E-posta: cceyhunarslan@ku.edu.tr

Submitted/Başvuru: 16.06 .2020

Accepted/Kabul: 23.12 .2020

\section{Citation/Atıf:}

Arslan, C. Ceyhun. "Frontier Orientalism and the Turkish Image in Central European Literature." Tarih Dergisi - Turkish Journal of History, 73 (2021): 277-282.

https://doi.org/10.26650/iutd.753511

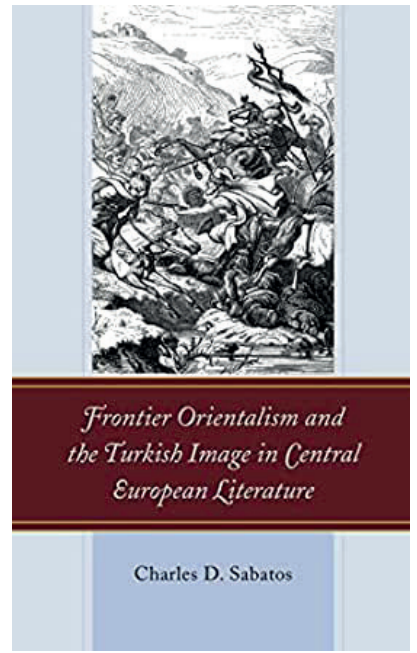


Frontier Orientalism and the Turkish Image in Central European Literature by Charles D. Sabatos traces the image of the Turk in works of Central European literatures that were written in different languages such as Czech, Slovak, and Hungarian from the early modern period to the present day. Sabatos employs the concept of "frontier Orientalism" to trace "[t] he evolution of the Turkish image from a historic threat to a mythical figure" and notes that this evolution played a key role in "the complex construction of modern European identities" (xii). The book is pertinent not only for specialists of Central European literatures but also for historians who work on sources that display complex transcultural relationships such as travel writings. Sabatos's focus on the Central Europe challenges much of the scholarly assumptions on the West that have often shaped earlier works on travel writing in Ottoman and Turkish studies. In particular, Frontier Orientalism demonstrates how current works on Orientalism sometimes generate a simplistic "West vs. Rest" dichotomy. Furthermore, Sabatos's work provides crucial remarks about the discipline of history as his work builds upon literary critics such as Hayden White who have reflected on the nature of history writing. After providing a brief summary of the book and discussing its contributions to diverse disciplines, this review will end with discussion of the new avenues of research that Sabatos's book opens up and other researchers can further explore in detail.

In the introduction, Sabatos elaborates the key concept of his work, frontier Orientalism. Sabatos here draws upon the anthropologist Andre Gingrich, who used the term to refer to a repertoire of concepts, myths, images, and metaphors that situate Austria vis-à-vis a borderline enemy and hence served the consolidation of a culturally heterogenous AustroHungarian Empire. Sabatos observes that Central European literatures also drew upon a similar repertoire as they developed a particular Turkish image throughout the centuries. Frontier Orientalism has some key differences from British and French Orientalism. For example, frontier Orientalism adapts better to diverse historical situations, does not describe all Muslims as evil, and combines both folk and elite art. Furthermore, unlike Central Europe, the British and the French developed the Orientalist discourse when both had a clear political and military superiority over what they called the "Orient."

In Chapter 1, Sabatos analyzes diverse travelogues and captivity narratives to discuss Stephen Greenblatt's concept of "self-fashioning." Greenblatt has argued that people during the early modern period started to view identity as manipulable and subject to social standards. Communities that are viewed as "enemies" also played a key role in the fashioning of identities during this time; however, Sabatos notes that Greenblatt has overlooked the key role that Ottomans have played in the self-fashioning of Europeans. During the early modern period, when the Ottoman Empire was at the zenith of its political and imperial power and posed a real military threat, many Central European writings generated an image of the menacing Turk that served to consolidate the cultural identity of their authors. Some 
of the sources that Sabatos analyzes include the captivity narrative, Treatise on the Morals, Customs, and Treachery of the Turks (1481) by the author known as Georgius of Hungary, the diplomat Pavol Rubigall's Latin Account of a Journey to Constantinople (1544), Hans Dernschwam's Diary of a Journey to Constantinople and Asia Minor (1553-55), and Štefan Pilárik's Pilárik's Fate (1666). These writings did not promote a one-dimensional understanding of the Turk and some of them even described Turks in affectionate terms. Works that were produced after the late eighteenth century when the Ottoman Empire no longer constituted a real military threat, such as Jozef Ignác Bajza's satirical The Adventures and Experiences of the Youth René (1783-5) and Daniel Šustek's Journey to Palestine (1874), perpetuated a new image of the Turk that symbolized anti-Enlightenment values and had little historical basis.

The second chapter focuses on poetry and folk tales. Sabatos draws upon Roland Barthes and argues that the "historical Turk" becomes replaced with the "mythical Turk" especially during the nineteenth century (25). Compared with their early modern counterparts, writings of the nineteenth century provided a static image of the menacing Turk that has become largely disassociated from the historical reality. Even when Slovaks had little direct contact with Ottomans, Slovak writings perpetuated a particular image of the menacing Turk in order to critique Habsburg rule. This period also witnessed the emergence of a national consciousness and the interpretation of the past through the prism of this consciousness. For example, Sabatos examines how Ján Kollár started to view folk songs from the past as expressions of an authentic national Slovak identity. Sabatos also observes nineteenth-century works in which Central European writers, like their Western European counterparts, sometimes express a sense of cultural and political superiority vis-à-vis Ottomans. Some of the sources that Sabatos analyzes include Gustav ZechenterLaskomerský's "From Slovakia to Constantinople" (1864) and Jan Neruda's Pictures from Abroad (1872).

Chapter 3 examines historical novels from the mid-nineteenth to mid-twentieth centuries such as Ján Francisci-Rimavský's Janko Podhorský (1844) and Géza Gárdonyi’s The Stars of Eger (1899). Sabatos notes that these works "used history as a metaphor" (xvii) as their narration of historical events was imbued with mythical elements. Unlike most of historical texts and romanticized poetic works, historical novels portray instances of personal and even intimate relations with Turks. Sabatos uses the term "displaced metaphor" to describe the use of Turkish image in Central European writings to critique Hungarian rule. Furthermore, Slovaks and Czechs often wrote about the resistance of Balkan people against the Ottoman Empire to express their discontent with and ultimate resistance against the Habsburg Empire. Sabatos also examines how different sources interpreted the same popular tales, such as the "Well of Love," which is about the Turkish lovers Omar and Fatima in Trenčín Castle. 
Chapter 4 examines how Central European literatures that were written during the interwar period described the Turk as a menacing and yet absurd character. The establishment of an independent Czechoslovakia in 1918 was a key event, since Slovaks were viewed as participants in state administration as opposed to mere subjects under Austrian and Hungarian rule. Some of the works that his chapter analyzes include Franz Werfel's The Forty Days of Musa Dagh (1933), Ludovít Janota's Slovak Castles (1935), and František Volf's collection of tales entitled Turkish War (1938). These works describe the Ottoman conquest to steer attention away from the looming danger that the Czechoslovak Republic felt as a state that was situated between the Nazi Germany and the Communist Soviet Union. This chapter also analyzes genres such as film and theatrical comedies.

Eventually, Tomáš Masaryk's vision of a democratic Czechoslovakia that served as a bridge between East and West became displaced with the vision of Communist camaraderie under the Soviet regime. In Chapter 5, Sabatos writes about the "Prague Spring," which started in 1968 when the Czechoslovak society experienced an important reform, although the Soviet and other Warsaw Pact troops halted the progress of this reform. Authors who were discontent with Soviet rule, Milan Kundera in particular, considered the Soviet conquest of Czechoslovakia as a form of colonization and used the image of the Turk and Ottoman domination to describe this discontent. Because of the heavy censorship, some other works in the second half of the twentieth century, such as Vladimír Ferko's Love in Slovakia (1988) and Pavel Vilikovský's Ever Green is . . (1989), used postmodern techniques to parody "the myth of endurance in the face of foreign oppression" (130). More recent novels such as Svetlana Žuchová's Yesim (2006) use the image of the Turk to flesh out the dizzying political and economic transitions of the postsocialist Central Europe. The conclusion briefly mentions that the relations between Turkey and Central Europe remain complex in the twenty-first century "when the Turk no longer represents a metaphorical or even mythical enemy" (157).

Sabatos's study of the history and literature of Central Europe from early modern period to present times provides a fresh perspective for Ottoman and Turkish studies that has often paid attention to either the Balkans or Western Europe when it has studied Europe. Unlike the Balkans, the Czechs and Slovaks did not remain long under Ottoman rule. Consequently, Czech and Slovak writers often wrote about the struggle of the Balkan people against Ottomans to express their disdain for the Habsburg rule. Furthermore, Central Europeans did not conquer Ottoman territories or have an overtly negative political or economic impact on the Ottoman Empire as did Russia, England, and France. Frontier Orientalism not only encourages more comparative work, but also emphasizes the need to generate new axes of comparison for such works. Even comparative works that do not claim to be Eurocentric often analyze non-Western or marginalized Western traditions in conjunction with a canonized Western tradition. Sabatos calls for a "minor-focused" approach, which compares Central 
European traditions among themselves rather than a Central European tradition with a major canonized Western tradition such as French. Therefore, Sabatos's work opens up new axes of comparison for future research.

Sabatos's work is also valuable because it notes the shortcomings of major theories and paradigms that shed light upon cultural interactions. Although Gellner's, Deleuze's, and Guattari's theories generate important insights, they overlook important historical details. Sabatos provides a nuanced critique of the Saidian scholarship that has shaped the study of oriental travel writing. He points out the relative fluidity of frontier Orientalism as opposed to Saidian Orientalism. Similarly, postcolonial critics like Said and Homi Bhabha have overlooked Central Europe in their works. Sabatos's work, therefore, challenges the easy division between the first-world West and the third-world Orient. Unlike much previous scholarship, Sabatos's work examines the phenomenon of Orientalism in a wide range of historical periods. It is also worth noting that Sabatos uses Slovak and Czech secondary sources from authors such as Tibor Žilka. Although Sabatos engages with key figures of cultural theory, his writing is free of the jargon that characterizes some of the theoretical scholarship and will be accessible to scholars from different disciplines, including history.

Sabatos also helps the reader to reflect on the nature of fiction and history writing, as he draws upon critics such as Linda Hutcheon who emphasize that history, like fiction, is a human construct. He examines postmodern works of fiction that foreground the discursive nature of history and the writings of Hayden White who demonstrates how writers "used history as a metaphor" (xvii). Even literary works can constitute an important source for historians as Sabatos calls into question the divide between fiction and non-fiction. Once scholars realize that this divide did not always exist for most cultures and time periods, they can start to view many literary works that Sabatos analyzes also as historical sources.

Frontier Orientalism is a pioneering work, as it introduces a plethora of new sources in each chapter. Although Sabatos provides a solid close reading of various sources, his need to cover new ground comes at the expense of not being able to analyze in detail all the sources he introduces. Further research can provide an in-depth examination of the works to which Sabatos could not pay much attention. Another avenue of research that Sabatos's work could not explore is a comprehensive comparison between Orientalism and frontier Orientalism. Compared to British or French Orientalism, frontier Orientalism may be more malleable; however, the British or French Orientalist discourse could still be full of contradictions and may be less rigid than often assumed. Finally, while Sabatos uses concepts from key figures of cultural theory, such as Linda Hutcheon, Georg Lukács, and Stephen Greenblatt to provide new directions for postcolonial studies and Central European literatures, other critics can offer exciting readings of Central European texts to provide a nuanced critique of 
these concepts. One could not expect Sabatos to explore all these vast and complex topics in one book; otherwise, Frontier Orientalism could have lost its focus. Rather, these topics are new frontiers of research that Sabatos's book opens up. Frontier Orientalism will be an invaluable source for both specialists of Central European literatures and scholars from other disciplines, such as history, who seek to have a more nuanced understanding of cultural interactions. 